\title{
Florida Springs Interdisciplinary Science Study
}

The Florida Springs Interdisciplinary Science Study is an integrated U.S. Geological Survey science effort that builds on the knowledge of Federal, State, and local partners to address serious human health and ecological concerns that have arisen regarding Florida's spring waters (Florida Springs Task Force, 2000). The steady increase in nitrate concentrations observed during the past 40 years threatens the aesthetic, cultural, and recreational value of these springs. The Upper Floridan aquifer, which supplies water to springs, is important not only for human consumption, but also for supporting critical ecological habitats for a variety of species. The USGS chose Manatee Springs as the location for this pilot study because of ongoing work being conducted by the Suwannee River Water Management District (SRWMD) and other scientific investigations supported by the State. The USGS work at this first magnitude spring will address the following objectives to build on existing work:

- Determine the major source(s) of nutrient enrichment;

- Develop baseline surveys of organisms that may be suitable for examining the ecological effects of nutrient enrichment in spring waters;

- Determine the occurrence of other contaminants of concern that could be associated with nutrient enrichment in spring waters (e.g. pharmaceuticals, pesticides and their degradates);

- Delineate areas most vulnerable to contamination based on geologic conditions and current land-use practices; and

- Assess how changing land-use practices have affected concentrations of nutrients and other contaminants in the spring.

\section{Springs in the Lower Suwannee River Basin:}

The first phase of the USGS Interdisciplinary Science Study is focused on Manatee Springs, a first-magnitude spring that discharges about 140 cubic feet per second (91 million gallons per day) of water from the Upper Floridan aquifer into a 1,200-foot spring run, which flows southward to the Suwannee River. Nitrate-N concentrations in Manatee Springs have increased substantially from less than 0.4 milligrams per liter $(\mathrm{mg} / \mathrm{L})$ in 1946 to more

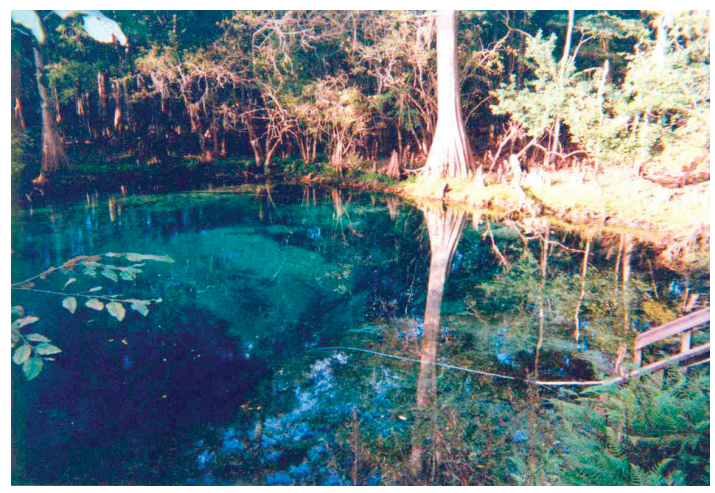

Figure 1. Photograph of main spring pool at Manatee Springs.

than $1.5 \mathrm{mg} / \mathrm{L}$ during the past few years. Elevated nitrate concentrations combined with high spring flows have contributed substantial loads of nitrogen to the Suwannee River from Manatee Springs as well as from several other first-magnitude springs along the river. Elevated nitrate concentrations in rivers can accelerate eutrophication, resulting in expansive algal blooms that deplete oxygen and may lead to fish kills or other deleterious impacts. Such adverse ecological effects have been indicated by an increase in periphyton biomass along the lower reaches of the Suwannee River (Hornsby and Mattson, 1998). Also of concern are the effects of high nitrate concentrations in the Suwannee River on the estuary of this river system, which together with the Suwannee River has been designated an Outstanding Florida Waterbody, a State Aquatic Preserve, and a National Wildlife Refuge.

\section{Ecological and Hydrogeologic Diversity of the Suwannee River System:}

The Suwannee River has the greatest diversity of subterranean decapod crustaceans anywhere in the world. These stygobiotic organisms are obligate cave dwellers that complete their entire life cycle in submerged underground systems. Yet, the distributions, abundances, ecological requirements, and sensitivity to changes in water quality of this fauna are still largely unknown. In addition, the existence of planktonic or nektonic microcrustaceans in aquifer habitats of north Florida is undocumented, despite their 
occurrence and diversity in south Florida and other major karst systems. The roles of subterranean fauna in the surface- and ground-water trophic web and the processing of nutrients have not been studied. Moreover, many of the hypogean species (those found underground, including both obligate and occasional cave-dwelling forms that require or prefer subterranean habitats for a portion of their lives) are thought to have limited populations that could be especially susceptible to ground-water perturbation, yet their status, sensitivity, and vulnerability are largely undocumented (Walsh, 2001). Based on these considerations, subterranean species are being evaluated as potentially important biological indicators of water-quality changes and for their suitability for long-term monitoring.

The hydrogeology of the Suwannee River basin is highly varied in terms of its underlying geologic framework, its complicated karst-dominated flow regime, water quality, and endemic aquatic habitats. The character of the Suwannee River changes dramatically as it flows downstream from southern Georgia, reflecting the hydrogeology, physiography, and land cover of the region it drains. Surface drainage characteristics dominate the upper two-thirds of the basin. A relatively thin layer of highly porous sands overlies the Floridan aquifer system in the southern third of the basin, where the Suwannee River reflects more groundwater characteristics. Downstream from White Springs, Florida, the Suwannee River receives inflow from over

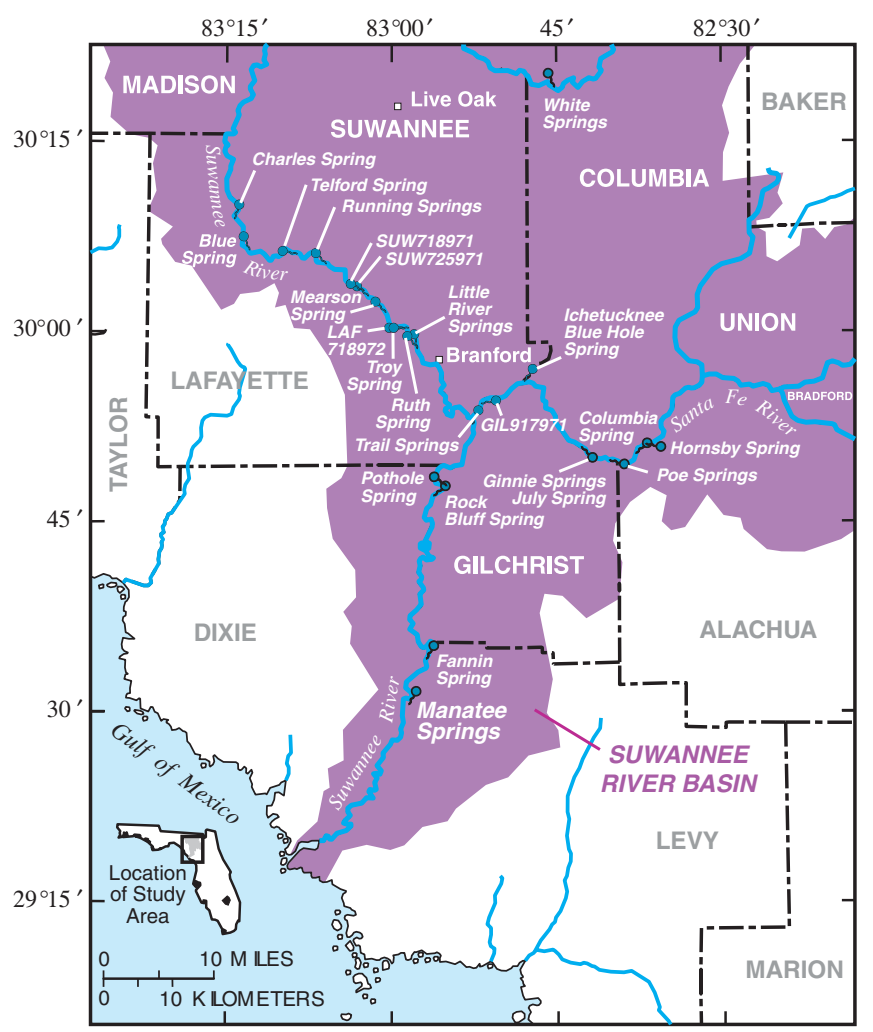

Figure 2. Map showing location of Manatee Springs and other springs sampled in Suwannee River Basin to assess sources and chronology of nitrate contamination.
200 known springs. The influx of ground water from the Floridan aquifer system buffers the acidity and darker color of predominantly tannic surface water with the relatively constant flow of clear, mineral-rich aquifer water. Relatively constant and elevated nitrate concentrations are observed in the middle and lower Suwannee River where spring inflow dominates the river water chemistry. Nutrients originate in part from fertilizers added to crops to stimulate growth, and from animal wastes from dairy and poultry operations. Animal wastes may also carry pathogens and bacteria, including the protozoan parasite Cryptosporidium parvum.

Besides agriculture, growing urban centers within the basin contribute additional sources of nutrients and contaminants.

\section{SCOPE AND METHODS OF MANATEE SPRINGS STUDY}

In the first phase of the study, innovative interdisciplinary techniques incorporating the fields of hydrology, geochemistry, microbiology, ecology, and geography are being used to study sources of nutrient enrichment on spring water discharging to the Suwannee River and associated ecological impacts. The state-of-the-art techniques described below have been used effectively in many diverse hydrogeologic environments; however, they are now being tested for their applicability in the complex karst systems found in the Suwannee River basin. It is hoped that scientific findings from this study will enhance work already being conducted at this spring by our partners and cooperators.

\section{Determining Sources of Nitrate:}

\subsection{Geochemical Tracer Techniques:}

Analyses of isotopic and other chemical tracers in water samples from Manatee Springs during base-flow conditions in 1998-2001 indicated that nitrate likely originates from both inorganic (fertilizers) and organic (animal and/or human wastes) sources of nitrogen.

Residence times of ground water discharging from the spring were highly variable and ranged from 7 to 27 years. Recent water samples collected by cave divers from several locations in the Manatee Springs conduit system indicated variable nitrate concentrations, which could be related to different land-use activities.

In this study, water samples are being collected from the main vent at Manatee Springs during base- and highflow conditions to assess the fate of nitrate during extreme flow conditions. To better resolve sources of inorganic and organic nitrogen in spring waters and to assess the fate of nitrate, water samples are being analyzed for both oxygen and nitrogen isotopes of nitrate. In addition, measurements of other chemical tracers, such as dissolved gases $\left(\mathrm{Ar}, \mathrm{N}_{2}, \mathrm{~N}_{2} \mathrm{O}\right)$, nitrogen isotopes of $\mathrm{N}_{2}$, 
and stable hydrogen and oxygen isotopes of water are being used to assess nitrate transformation reactions in the aquifer due to denitrification or other processes.

The age or average residence time of ground water discharging from these springs is being estimated using transient tracer techniques during base-flow and highflow conditions. The spring water age can be used to assess the relative proportions of young water from shallow parts of the aquifer and older water from deeper parts of the aquifer (Katz and others, 1999). Water samples are being collected and analyzed for the transient environmental tracers: chlorofluorocarbons $\left(\mathrm{CCl}_{3} \mathrm{~F}, \mathrm{CCl}_{2} \mathrm{~F}_{2}\right.$, and $\left.\mathrm{C}_{2} \mathrm{Cl}_{3} \mathrm{~F}_{3}\right)$; tritium and its decay product, helium-3; and sulfur hexafluroride (Katz and others, 2001).

Other tracers of ground-water discharge that are being used include naturally occurring radium (Ra) isotopes $\left({ }^{223,224,228,226} \mathrm{Ra}\right)$ of the Uranium-series decay chain. Briefly, these four naturally occurring $\mathrm{Ra}$ isotopes have a very different geochemical signature in freshwater compared to mineralized aquifer water. This attribute, in addition to well-known source functions, a wide range of half-lives

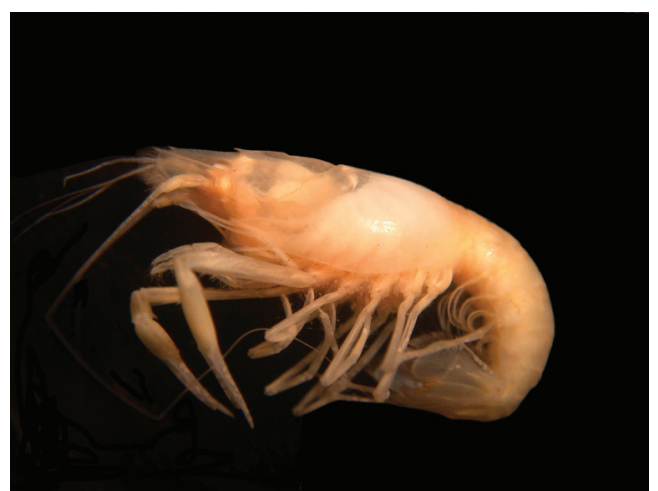

Figure 3. Photograph of the pallid cave crayfish (Procambarus.pallidus), a blind cavedwelling crustaceon found in ground water of the Floridan aquifer in the Suwannee River Basin.
(3.6 days to 1,600 years), and highly elevated groundwater concentrations make radium an ideal tracer to examine surface-water to ground-water exchange across the riverbed interface (Swarzenski, 1999).

\subsection{Microbiological Tracer Techniques:}

Standard and state-of-the-art microbial water-quality indicators are being used to screen water samples to determine if spring waters are being influenced by fecal sources (Griffin and others, 1999, 2000). Source tracking assays are being employed to differentiate between animal and human fecal contamination using $\mathrm{F}^{+}$specific RNA coliphage and human-specific virus assays. A viral tracer study is being conducted to determine if areas around Manatee Springs affect water quality through focused recharge, such as through sinkholes or other solution features.

\section{Inventory of organisms for monitoring water-quality effects:}

Exploratory surveys are being conducted during baseand high-flow conditions to assess the current status of the hypogean community in the spring system. Understanding the diversity and relative abundance of the stygobiotic organisms in various parts of the spring system is essential to identifying species vulnerable to nitrate contamination and those that would be suitable for further water-quality monitoring. Organisms that exhibit both positive and negative sensitivities to water quality changes are being evaluated for long-term monitoring or physiological experimentation. By initiating studies of this unusual fauna, multiple avenues of research are likely to be found for evaluating trophic linkages, ecological functions, and community responses associated with anthropogenic disturbances.

Surveys of the stygobiotic fauna utilize three principal sampling methods: (1) pumping and filtering water from existing wells and solution cavities to sample microcrustaceans; (2) using of borehole videography to visually count macroinvertebrates; and (3) diving in spring vents, caverns, and large conduits to conduct transect surveys and to estimate population abundances of decapod crustaceans. Organisms are collected by qualitative and quantitative methods, preserved, and distributed to taxonomic specialists for systematic identification. In association with hydrochemical, geophysical, and geographic information, biological data can then be analyzed to determine patterns in diversity, distribution, or abundance of the stygobiotic fauna as a function of water-quality characteristics, flow conditions, land-use activities, and other integrators of physical conditions as they relate to ecological responses.

\section{Assessing the occurrence of other contaminants from agricultural activities:}

Information is limited concerning the occurrence of "exotic" contaminants, such as pharmaceuticals, bacteria, pesticides, herbicides, and their transformation products (degradates) in water from the Upper Floridan aquifer. However, herbicides have been detected in trace concentrations in 9 of 15 springs discharging from the Upper Floridan aquifer in southern Georgia (Hippe, 1997). Pesticide and herbicide use is potentially high in the Suwannee River basin due to large crop acreages of corn, peanuts, tobacco, and watermelons in the middle and lower Suwannee River basin. Low concentrations of these compounds, and their transformation products, may result in observable effects on aquatic organisms and pose an environmental risk (Kolpin and others, 2002). Water samples from Manatee Springs are being collected and analyzed for selected pesticides, herbicides and their metabolites, and antibiotics to assess the occurrence of contaminants (other than nutrients) associated with various agricultural activities in the basin. 


\section{Contributing Scientists:}

DALE W. GRIFFIN, Microbiologist, e-mail: dgriffin@usgs.gov

PETER W. SWARZENSKI, Geologist, e-mail: pswarzen@usgs.gov

U. S. Geological Survey

Florida Integrated Science Center

$6004^{\text {th }}$ St. South

St. Petersburg, FL 33701
STEPHEN J. WALSH, Research Biologist, e-mail: steve walsh@usgs.gov

HOWARD L. JELKS, Research Biologist, e-mail: howard jelks@usgs.gov

U.S. Geological Survey

Florida Integrated Science Center 7920 NW $71^{\text {st }}$ St. Gainesville, FL 32653

\section{Delineating the contributing area to the spring and assessing land-use changes:}

The SRWMD recently installed nine monitoring wells in the vicinity of Manatee Springs. Water-level data from these wells provides critical information on ground-water flow patterns near the spring, and are being used by SRWMD to construct a high resolution map of the hydrologic contributing area to the spring. These data are being used to calibrate an existing ground-water flow model and particle tracking model to assess ground-water flow to the spring. The contributing area of the spring mapped by SRWMD will be used to spatially analyze land-use data, soil distributions, water-use patterns, and population data to identify potential sources of nutrients and to estimate the nutrient contributions from each source based on the latest land-use compilations. Recent aerial photography is being incorporated with 1994 land-use coverages to determine land-use changes that have occurred in the basin during the past 5-10 years so that current observations can be considered in the context of future estimates of nutrient loading.

\section{SUMMARY}

Several water-quality monitoring programs involving springs are already underway by State and local agencies, as are baseline faunal and floral inventories, contaminant and experimental studies, and investigations to examine organism and community-level responses. Integrating techniques from multiple disciplines within the USGS is a powerful approach for assessing sources of contamination to ground-water resources and potential effects on ecosystems. This integrated information from several fields of study, will reduce the uncertainty regarding the identification of anthropogenic sources of contamination in ground water discharging from springs. Understanding how human activities on the surface affect the aquifer system, will aid the development of more effective strategies to protect spring waters from further degradation and remediate springs that are already contaminated.

\section{REFERENCES}

Florida Springs Task Force, 2000, Florida's springs: Strategies for protection and restoration: Report prepared for the Florida Department of Environmental Protection, $57 \mathrm{p}$

Griffin, D., Gibson, C.J. III, Lipp, E.K., Riley, K. Paul, J.H., and Rose, J.B., 1999. Detection of Viral Pathogens by Reverse Transcriptase PCR and of Microbial Indicators by Standard Methods in the Canals of the Florida Keys: Applied and Environmental Microbiology, v. 65, p. 4118-4125.

Griffin, D. W., Stokes, R., Rose, J.B., and Paul. J.H., 2000. Bacterial Indicator

Occurrence and the Use of an $\mathrm{F}^{+}$Specific RNA Coliphage Assay to Identify Fecal Sources in Homosassa Springs, Florida: Microbial Ecology, v. 39, p. 56-64.
Hippe, D.J., 1997, Pesticide occurrence in the Upper Floridan aquifer in the Dougherty Plain and Marianna Lowlands districts, southwestern Georgia and adjacent areas of Alabama and Florida: Proceedings of the 1997 Georgia Water Resources Conference, University of Georgia, Athens, Georgia, p. 65-67.

Hornsby, H.D., and Mattson, R., 1998, Surface water quality and biological monitoring network: Suwannee River Water Management District Annual Report WR-98-02.

Katz, B.G., Hornsby, H.D., Böhlke, J.K., and Mokray, M.F., 1999, Sources and chronology of nitrate contamination of springwaters, Suwannee River Basin, Florida: U.S. Geological Survey WaterResources Investigations Report 994252, $54 \mathrm{p}$.

Katz, B.G., Böhlke, J.K., and Hornsby, H.D., 2001, Timescales for nitrate contamination of spring waters, northern Florida, USA: Chemical Geology, v. 179, p. 167-186.

Kolpin, D.W., Furlong, E.T., Meyer, M.T., Thurman, E.M., Zaugg, S.D., Barber, L.B., and Buxton, H.T., 2002, Pharmaceuticals, hormones, and other organic wastewater contaminants in U.S. streams, 1999-2000: A national reconnaissance: Environmental Science and Technology, v. 36, p. 1202-1211.

Swarzenski, P.W., 1999, Re-examining freshwater-saltwater interface processes using radium isotope systematics. U.S. Geological Survey, FS-065-99, 2p.

Walsh, S.J., 2001, Freshwater macrofauna of Florida karst habitats, in Kuniansky, E.L., ed., U.S. Geological Survey Karst Interest Group Proceedings, U.S. Geological Survey Water-Resources Investigations Report 01-4011, 211 p. 